\title{
Negotiating green space between ecological threats and beloved objects
}

\section{Dr Thor Kerr}

Department of Communication and Cultural Studies, Curtin University, Perth, Australia

School of Media, Culture and Creative Arts, Curtin University

GPO Box U1987, Perth

Western Australia, 6845

Australia

Telephone: +61 892662732

Mobile: 0410420714

Email: Thor.Kerr@curtin.edu.au

Website: $\underline{\text { www.curtin.edu.au }}$

Thor Kerr is a Lecturer in Curtin University's School of Media, Culture and Creative Arts. His research focusses on media and public representation in negotiations of urban space, particularly in relation to green built environments, native title and heritage sites. 


\section{Negotiating green space between ecological threats and beloved objects}

This paper is directed at furthering understandings of the function of space, time and sensory experience in environmental discourse. It does this through an empirical study of the publicity campaigns and counter campaigns around North Port Quay, proposed as a sustainable property development project for coastal waters off Fremantle in Western Australia. The case demonstrates how a proposed ecological improvement project is contested in discursive struggles over the space and time of environmental problems. It shows how representations of an immediate threat to local environment can be more powerful than representations of a model solution to future global ecological crisis. The radical imposition of a futuristic island town by the beach triggered an effective, localized popular movement unified through people's desire to restore their sensual experiences of local environment. This desire linked people's diverse demands for conservation behind a discursive frontier against anyone supporting North Port Quay. Standing for 'our beaches' against the proposed sustainable development not only blocked the project through localized practices of institutional democracy, it also helped transform the institutional political landscape of Fremantle.

Keywords: environmental discourse; ecological modernization; green built environment; sensory experience; empty signifier

\section{Introduction}

This paper offers an explanation of how space, time and sensory experience function in public conversation around environmental policy in an age of scientific subjectivity (Latour 2004). Its aim is to support analysis of blockages and seemingly contradictory events in the production of environmental policy, such as climate campaigner Al Gore's endorsement of mining magnate Clive Palmer's parliamentary strategy that ended Australia's carbon tax (Massola, Arup and Aston 2014). Like the Palmer-Gore press conference, this paper locates the significance of an event in $\mathrm{Oz}^{1}$ within broader environmental discourse (Dryzek 2005). 
The claims made here are drawn from an empirical study of the social negotiation of meanings of environmental threats and solutions in relation to the North Port Quay (NPQ) property development, proposed for construction over urban coastal waters in Western Australia. In justifying the imposition of this walled island town over 345 hectares of seabed near Fremantle Port, the project consortium claimed that NPQ could become 'the world's first carbon free development' (Fremantle Herald, June 14, 2008). Despite being promoted as a sustainable development, the project was blocked by community resistance channelled through localized practices of institutional democracy. Analysis of this case offers insights into how green spaces are negotiated between heterogeneous readings of ecological threats and antagonisms stimulated by threats to people's sensory experiences of familiar environments. NPQ was promoted as an important sustainable development in the face of global ecological crisis, but it was seen by many as an imposed immediate threat to local environment, particularly beaches. Community resistance to the project was successful because the dominant environmental problem associated with the project shifted rapidly in public conversation from proponents' description of long-term global ecological threats to opponents' talk of the project immediately threatening their local environment, where beach aesthetics were a powerful trigger for social action. People were moved by an immediate call to defend the beach, not by a scientific demand to allow a 'significant demonstration of the carbon-constrained future' (Fremantle Herald, August 16, 2008). Standing for 'our beaches' (Fremantle Herald, August 30, 2008) was a powerful symbol that unified popular resentment against coastal property development. It worked because it engaged people's desire to restore sensual experience of the local environment. This desire - symbolized by defending 'our beaches' - was sufficiently moving and ambiguous for it to be the empty signifier that unified a local popular 
movement blocking North Port Quay. This case demonstrates how space, time and sensory experience function in public conversation and policy making around the contested site of a proposed ecological improvement project.

\section{Global ecological crises and localized environmental movements}

This case study builds on the work of Maarten Hajer in analysing social constructions of environmental problems, policy solutions and localized community responses. Hajer (1995) applied discourse analysis techniques to describe how environmental policymaking around acid rain was influenced not just by interest groups but by institutional practices and the interplay of narrative and metaphor as well as naturalisation and omission. Hajer also found that sensory experience - such as parliamentary excursions to sites of dying trees - could be employed to influence policy even if representation of sensory experience was problematized by demands for scientific evidence. This power of sensory experience was investigated further by Hajer (2003) in a study of community reaction to a state-sponsored ecological improvement program. Hajer's study described a diverse group of people forming a contingent social movement in response to 'the looming threat' (97) of environmental change being imposed in a rural area by the Dutch government. Symbolizing naturalized rural aesthetics - by installing giant picture frames within fields - helped to unify a community frontier against the government's 'nature development' policy of replacing farmland with a more diverse ecology (Hajer 2003, 90). This frame-in-the-fields social movement demonstrated how nature development policy threatened its members' idealized landscape. The policy made them aware of what they felt 'attached to, thus influencing people's sense of collective identity' (Hajer 2003, 89). The movement came together when its members' subjective attachment to a particular system of meaning was threatened. Disruption to a system of meaning stimulates antagonism as people 
construct an enemy responsible for preventing the realization of their lived-out identities (Howarth 2000). The antagonized may be contingently unified in a social movement if their heterogeneous demands against an enemy are incorporated in an empty signifier (Laclau 2005). That is, a signifier that links the variety of demands in a chain of equivalence. Arguably, the frame in the fields, described in Hajer's (2003) work, functioned as an empty signifier supporting a variety of demands: from calls for local input on environmental policy to a general longing for the way of life idealized in representations of Dutch landscape painting. Aesthetics is important because radical emotional investment in the empty signifier motivates people to unify behind a community frontier (Laclau 2005). This investment is stimulated by affect: the 'visceral forces... other than conscious knowing' that drive human thought and movement (Gregg and Seigworth 2010, 1). Indeed, Thrift (2008) has shown how affect plays an increasingly important role around local targets for political action. Laclau (2006) has appealed to psychoanalytical theory to explain how this dynamic operates through subjects' emotional response to an object. The gap between objet petit $a$ and the Thing in Lacanian theory is the basis of all signification, argues Laclau (2006); and this symbolic mediation relies on the operation of sensory experience. While Freud (1991) associated sensual experience with desire for the maternal object, Kristeva saw potential social power in the heterogeneity of this object: 'mother-woman is a rather strange "fold" (pli) which turns nature into culture, and the "speaking subject" (le parlant) into biology'... this heterogeneity... literally explodes with pregnancy - the dividing line between nature and culture' (Kristeva \& Goldhammer 1985, 149). Returning to Freud, Copjec (2004) argued that subjects were motivated by partial drives that content themselves with 'the simulacra of the lost (maternal) object' (34). The psychoanalytical sense of the relation between objet petit $a$ - as in 'I love in you something more than 
you' (Lacan 1981, 268) - and Freud's drives elucidated by Joan Copjec (2004) can provide a way of understanding how the relation between beloved object and affective investment is a source of dissatisfaction stimulating the fabrication of community laws and ideals (Copjec 2004). It could be said that discourse is fuelled by sensory experience and desire for something missing. But how does this subjectivity to sensory experience and desire for something missing operate in the dynamics of environmental discourse? Analysing public conversation around a proposed green building project can provide an answer because it typically includes representations of environmental problems as well as local knowledge, heritage and affective investments as well as narratives of future solutions to global ecological crisis.

\section{Green buildings and engaged publics}

Built environments are seen as important sites for negotiating responses to ecological crisis since they can be shown to account for a third of the world's energy-related carbon dioxide emissions (Koeppel and Ürge-Vorsatz 2007). Actors within the building industry have promoted green building as a solution to the crisis, particularly the ecological threat of climate change (Miller 2010). The World Green Building Council says it has shaped a network of over 90 national organizations 'to promote local green building actions and address global issues such as climate change' (as of its website on November 6, 2012). The council guides its national member organizations on the promotion of green building markets and establishment of green building certification systems, which work to influence and stabilize national meanings of green building, often supporting radical new forms of built environment. The legitimacy of these certification systems, such as Green Star in Australia, are contingent upon negotiations within expert networks made up of representatives of industry, government and academia as well as subsequent successful market take-up and public relations (Kerr 
2009). While accreditation systems for green built environments tend to be negotiated by interested parties at a national level, individual green built environment projects are negotiated (O’Neill and Gibbs 2013) at local levels if they are to be read as appropriate responses to environmental threats by people with affective investments (Copjec 2004) in and around their proposed construction sites. A comparative study of green urban development has found that meanings of sustainability were determined by conflicts rooted in each location's complex geography amid contradictory economy-environment relations of post-industrialization (While et al. 2004). In other words, associating sustainable development with a building project depends upon the particular cultural milieu of its negotiation. Frustration around the open meaning of green built environment supports the argument for 'radical departures from normal planning and decision making processes' (Kenworthy 2006, 82) so that creating green built environments can become a technocratic response to the vision statements of constructed publics (Gottweis 2008) rather than a means of dealing with the antagonistic struggles of engaged publics (Dahlgren 2009) around building sites. However, limiting policy making to the domain of engineers and other experts guided by the futuristic vision statements of constructed stakeholder groups could deny other possibilities for civil agency emerging from private into public spheres as arenas of contested representations and interests rather than the domain of consensual facts and figures (Lucy and Mickler 2006). Analysing a sample of texts from public campaigns for and against a green building project can provide insight into the operation of space, time and sensory experience in environmental discourse.

\section{Methodology}

Discourse analysis techniques were applied in a close reading of texts containing representations of ecological threats in an empirical study of a proposed green built 
environment project: North Port Quay in Fremantle, Western Australia. The analytical approach relied on a synthesis of theoretical insights on environmental discourse (Hajer 1995, Harvey 1996, Bakker and Bridge 2006, and While et al. 2010), antagonism (Howarth 2000) and property relations (Harvey 2000), popular movements (Laclau 2005), affective investment (Copjec 2004), media and political engagement (Dahlgren 2009), representations in place (Scollon and Scollon 2003) and the symbolic function of beaches in Australia (Perera 2009). Investigation of the NPQ case focussed on how meanings of green built environment were negotiated during its publicity campaigns and counter campaigns in the local cultural milieu. Newspaper, television and Internet media were scanned and public meetings recorded in collecting an archive of 723 texts produced between 29 May 2008 and 31 December 2009 referencing North Port Quay. A corpus of 180 discourse samples were selected from the archive on the basis of a text containing a reference not just to the project but also to an ecological threat, environmental threat or their proposed solutions. These corpus texts were transcribed and stored in a server as word processor texts and digital images for reflexive coding (Rapley and Flick 2007) by media sources, speaker cases, thematic nodes, chronological phase and media genre. After coding, the corpus was examined for indications of discursive mechanics (Chouliaraki 2008a, and 2008b, Hajer 1995), intertextuality (Shapiro 2001) and interdiscursivity (Bhatia 2008). Methods of corpus-supported critical discourse analysis (Lee 2008) were also applied to identify significant objects and transformations in the corpus. Further research into these significant objects was conducted by reviewing relevant literature and undertaking on-site place readings. The analysis focussed on meanings and identities, and how these influenced truth production by policy-making institutions.

\section{The remoteness of Utopia}


The North Port Quay consortium was inspired and led by Greg Poland of Strzelecki Group, which operated large marina developments on Perth's metropolitan coast. In a promotional video on North Port Quay's website (accessed November 13, 2009), Poland said he intended NPQ to be an enduring symbol of green built environment benefitting his heirs and the people of Western Australia:

This is going to be around for decades, generations, hundreds of years, thousands of years hopefully. I don't want my children, definitely don't want my grandchildren, great grandchildren to look at me and say he was a vandal. I want them to say he was visionary... And did not under any circumstances do anything wrong environmentally.

Poland positioned NPQ as an enduring project that would produce future heritage rather than vandalize local heritage; plausibly, the tourist-attracting, colonial heritage of Fremantle (Kerr, 2012b). The moral position supporting Poland's legacy attempt was constructed around doing the right thing. Earlier in the video, Poland said this was not always his vision as a developer but that he had become smarter and more educated with age. Poland also suggested that he and other property developers had conceived NPQ before recruiting Peter Newman to help make the project 'environmentally friendly and carbon free'. Professor Newman directed the Fremantle-based Curtin University Sustainability Policy Institute, and he was known locally as the urban planner who had campaigned successfully to save Fremantle's railway service from government closure. NPQ was promoted as an upmarket marina property development to be the 'World's First Carbon-Free Development' (Fremantle Gazette, June 3, 2008) in its initial advertisements, published between 31 May and 7 June 2008. The NPQ homepage (accessed October 26, 2009) showed a video simulation of the project turning from a plan superimposed over the sea, to emerging grey blocks turning into a colourful island town, a utopia. The homepage included alternating background images of coastal 
leisure as the simulation's voiceover introduced NPQ's coastal location and leadership in, a suggested, ecological-modernizing contest to be the most 'environmentally sustainable development':

Voiceover: Nestled between Indian Ocean and Perth, North Port Quay will set a new standard in environmentally sustainable development. North Port Quay will set the standard by which all other developments will be judged. Homes and businesses will be powered by wind, wave and solar energy. It will be a carbonfree development that actually creates a better environment.

The voiceover described NPQ as 'a place for people with homes, schools, cafes, beaches, fishing platforms, cycle paths and walkways', but the simulation showed nobody cycling, walking or fishing. Instead, cars drove over bridges and along the seawall around the hyper-modern town. This inconsistency was detected by media workers reporting NPQ's launch (ABC News WA 2008) on 29 May:

Reporter: The development would be powered with renewable energy VLS High Angle. Simulation of urban islands behind seawall. Camera pans left.

Reporter: but with cars allowed on the islands the proponents were forced to qualify

MS High Angle. Simulation of seawall, with cars on it, a canal in middle ground and buildings, roads and trees in background. Camera pans right along seawall with cars travelling upon it.

Reporter: their claim that it would be one of the world's first carbon-free developments.

CS. Peter Newman sitting in the same place as Project Director Chris Carmen was earlier. Subtitle: 'Peter Newman NORTH PORT QUAY'.

Peter Newman: It's going to be carbon-free in terms of the the way in which the people who are living there are powered.

LS High Angle. Simulation of a large low-rise structure, with several medium-rise buildings, a canal then the seawall, ocean and the coast behind it, a canal and several low-rise buildings on left. Camera pans left.

Reporter: The project has the financial backing of 40 of the state's most influential business people. 
Amid simulations of the NPQ future, news reports incorporated current images of the beach and coast as visual elements with voices of opposition to NPQ. Growing opposition was constructed with viewers informed that NPQ meant the seabed would be occupied by wealthy developers and nearby public beaches eroded. News footage cut back and forth mainly between the simulated futuristic canal town and its site of coastal waters by the port facility, a beach or ocean horizon. The NPQ simulation succeeded in capturing but not controlling media attention. Responses to NPQ's media launch suggest that the simulated seawall was reinscribed, by local audiences, with ecological threats such as rising sea levels, global warming and climate change. Audience members also read a threat of carbon emissions in images of vehicles travelling along NPQ's seawall and its powerboats berthed inside the wall. Despite NPQ emerging magically from the sea with no sign of construction activity in its publicity simulation, some audience members read that NPQ meant a long, disruptive, construction process with vast carbon emissions.

The consortium responded by replacing its initial advertising series with 'MYTH VERSUS FACT' advertisements (The West Australian, June 7, 2008). The myths in this advertisement indicate how the consortium interpreted NPQ's popular reading in the wake of its launch:

\footnotetext{
MYTH: It will be overwhelmed if there is a tsunami or a rise in sea levels due to global warming.

FACT: North Port Quay has been planned, and would be developed, taking into account the effects of climate change and global warming. The concept plans accommodate anticipated sea level changes with one in 100-year events. Residents of North Port Quay would be more protected than those in most other suburbs on the coastal plain.
}

MYTH: Venice is sinking. This will also sink over time. 
FACT: Venice was built more than 900 years ago on wooden piles. Engineering and construction processes have come a long way... North Port Quay would be in line with world best practice.

\section{MYTH: The scale of it is "over the top."}

FACT: It is the very scale of the concept that allows North Port Quay to be a world-leading example of sustainable development...

\section{MYTH: It will become a gated community and an enclave for the rich.}

FACT: The North Port Quay concept offers open public access and a wide range of community benefits, including an allocation for affordable housing and three new public beaches... The concept area covers 345 ha of seabed; but less than 75 ha of land is proposed for housing. (The West Australian, June 7, 2008)

The third series of NPQ advertisements, from 14 to 28 June, envisaged the project becoming the 'world's first carbon-free development' (Fremantle Herald, June 14, 2008). Proponents positioned it as world-best practice in 'sustainable development', framing sustainable development within a competitive system. A later advertisement (Fremantle Gazette, February 10, 2009) focused on world best practice in ecological modernization being incorporated into NPQ. However, sustainable development tended to be read locally as something opposing the material excess typically inscribed in NPQ's imagery. Professor Newman, challenging media problematization of NPQ's sustainability claims, wrote in the press: 'There is often an implication that it is somehow impure to support "developers" and that sustainability cannot be facilitated by such wealthy projects' (Fremantle Herald, August 16, 2008). Newman described past cases of sustainable development occurring at a communal level in Fremantle, providing 'models to others on how to live more sustainably within their own suburbs' (6). An earlier opinion piece by Norman Erickson (Fremantle Herald, June 28, 2008), suggested that NPQ was an 'elitist' non-antidote to 'the very unsustainable form of development which is creating both environmental and social (affordability) issues'. Erickson advocated a 'bottom-up' approach to sustainability via small clusters of state- 
supported community dwellings with their own renewable power generation and food production capacity. Sustainable development has a history of being understood like this, particularly as a solution to overpopulation and resource shortages (World Commission on Environment and Development 1987). These threats were invoked by NPQ's planned introduction of 20,000 more local residents (Fremantle Gazette, June 10, 2008), disrupting the consortium's intended reading of sustainable development. Opponents also argued that NPQ would require vast carbon-emitting resources to be built at sea - not just the substantial financial resources and ecological modernizing technologies emphasized by proponents. The immediate threat of noise, air, water and visual pollution from NPQ's construction as well as the threatened loss of beach environments to erosion, property developers and future residents were more powerful threats to many locals than the lack of a carbon-free sustainable development associated with NPQ. When this had become obvious, NPQ replaced its sustainable development advertisements in April and May 2009 with a series of advertisements dominated by an image of the local beach, suggesting a common experience of the beach with readers and the importance of preserving a coastal way of life.

The year-long campaign by the consortium to legitimize NPQ locally by suggesting it was an acceptable form of future green built environment effectively ended when The Greens candidate, Adele Carles, won the Fremantle by-election in May 2009 after campaigning against the project. The consortium's intended reading was not realized partly because NPQ signified ecological threats to local audiences without offering them solutions to these particular threats. In other words, NPQ did not offer an ecological problem and corresponding solution acceptable for discursive reproduction in the local media. Representation of a mutually reinforcing ecological threat and corresponding solution is a significant feature of ecological modernization (Hajer 1995) 
and green building (Kerr 2009) discourses. Yet, the lack of a mutually supporting ecological threat and solution in NPQ's popular reading does not explain how local audiences became so antagonistically unified against the project.

\section{The immediacy of 'our' environment}

Besides the problematic positioning of NPQ solving ecological threats, the analysis found that its threatening imposition stimulated its own resistance. ${ }^{2}$ NPQ antagonized local people by threatening their love of objects experienced in their environment. NPQ threatened their desire to restore sensual experience of these environmental objects, and this desire unified a popular discursive frontier against NPQ.

Representations of environmental destruction or threats of destruction in the corpus were most commonly associated with local beaches and coastal places. They were less commonly associated with metropolitan Perth or the state of Western Australia. They were rarely associated with Australia or the world. Metropolitan, state, national and global scales were more commonly associated with sustainable development, while carbon control was almost always associated with global scale. NPQ was positioned by its proponents in association with carbon control and sustainable development at global scale and, in various instances, at state and metropolitan scale. While the project was positioned as a leading solution within a global contest of ecological modernization, local places were blurred and backgrounded in NPQ's simulation and left out of its initial promotional images. Its opponents, however, typically foregrounded local places, particularly beaches, in association with a looming threat of NPQ. This repositioning of NPQ in its immediate spatial context was essential to the construction of an emerging controversy around the project in the $\mathrm{ABC}$ news report, described above, on project launch day. Project place and controversy were linked in the anchor's first sentence introducing this news piece: 'A controversial plan 
to build a six billion dollar man-made island village off the coast of Fremantle is already drawing fierce opposition' (ABC News WA 2008). Opponents didn't just position NPQ in a local rather than global environmental context, they also spoke of it in an immediate rather than distant future, which is where proponents of NPQ had attempted to locate it. Professor Newman argued early on that NPQ required 'significantlydifferent thinking as we approach a carbon-constrained future' (Fremantle Herald, June 7, 2008) Later, responding to overwhelming local opposition, Newman said NPQ was read as an appropriate sustainable development by distant audiences:

I have spoken about urban resilience and sustainability with NPQ as an example, in the US, across Australia and last week in Canada at a big local government sustainability conference. No-one has said this is obviously "unsustainable", they just want to know more. Since NPQ first announced its approach to create a development which would produce more renewable energy than it needs, thus compensating for any fossil fuels used in its building, there has been a number of global moves supporting this as a mainstream process. (Fremantle Herald, June 27, 2009)

The consortium initially positioned NPQ in relation to environmental problems at the spatial scale of state and planet (Fremantle Herald, June 14, 2008). However, the tenability of positioning NPQ as a future solution to ecological threats by reference to state or world space quickly deteriorated as other voices in the local media repositioned NPQ as an immediate threat to local space. This repositioning of NPQ as an environmental threat occurred through representation of its immediate spatial and temporal relations to local beaches and other objects. In other words, this shift in representation from an acceptable NPQ to a rejectable NPQ relied on the project's temporal and spatial contexts being shifted from distant global future to local immediacy. For example, the project was problematized in the local distant future after several years of reclamation and construction - by Fremantle Ports CEO Kerry 
Sanderson: 'the traffic chaos that would ensue from the additional 40,000 vehicle movements each day on the north Fremantle peninsula' (Fremantle Herald, July 12, 2008). Also, it was problematized in the global immediate future because of carbon emissions from its site reclamation and construction: 'carbon-neutral claims needed to be tested against energy used to create the massive... development, not just the energy to run the completed project' (Fremantle Herald, June 14, 2008). Representations against NPQ tended to rely on threats in both close spatial and temporal proximity: 'If this development is allowed to go ahead, you will lose your beaches, surf clubs and restaurants due to coastal erosion' (Fremantle Herald, June 21, 2008). An article, headed 'The end of our beach, warns Cottesloe mayor', reported: 'People who value those beaches ought to be concerned' (Fremantle Herald, June 28, 2008). Such threats relied on readers' pre-existing sense of beach culture, social status and aesthetics: 'We, the working Western Australians cannot live by the beach in expensive suburbs but have always had the free beaches and the free horizon to go to escape suburbia' (Fremantle Herald, June 28, 2008). NPQ was depicted destroying this 'free horizon' for people who could not afford to sail out past it. In the 2008 state-election campaign, Adele Carles of The Greens appropriated this emerging popular reading of NPQ threats:

\footnotetext{
"Fremantle is under siege. We could lose what is so special about [it]. Social, heritage and community are all up for grabs... We are against seabed being privatized - it's an insult to the Australian way of life. We love our views...," Ms Carles said about NPQ's plans. (Fremantle Herald, July 5, 2008)
}

The merging of culture and nature was a key feature of environmental threats in representations against NPQ. These threats were seen from readers' particular positions. Threats from an aggravated natural environment were often articulated as threats to cultural objects such as buildings, a car park or a veggie patch. Threats to the natural environment were articulated as threats to particular environmental experiences or 
aesthetics. The threat of NPQ disrupting the vista from Port Beach, for instance, was a threat to the relations between people and what they could see and otherwise sense in the immediate environment:

I SAW a whale the other day at Port Beach, North Fremantle... close enough to point out to my 3-year-old twin boys.

They saw its fin and tail splash out of the water and I thought how lucky we were. Then I looked towards Rous Head and tried to imagine high-rise buildings... I couldn't picture it - it was all too ugly and destroying the moment I was having with the whale.

I turned back to focus on the beautiful creatures, just in time to see her squirt water into the air, as if to say hello... experiences like this are sacred. (Fremantle Herald, June 7, 2008)

The editor's response to this letter suggests that NPQ was being read as a process of appropriating the aesthetic then selling it to others. The representation of NPQ threatening people's aesthetic relation to local environmental objects characterized local vox populi resistance to the imposition of NPQ.

\section{Desire to restore sensual experience}

The local immediate threat of North Port Quay to the bodily experienced environment of readers stimulated the construction of a discursive frontier (Laclau 2005) against NPQ behind which a variety of demands could aggregate around a popular defence of 'our beaches'. Standing for our beaches and against NPQ was a major feature of The Greens' campaign before Western Australian parliamentary elections in September 2008, in which Greens candidates Lynn MacLaren won an upper house seat and Adele Carles recorded a substantial swing against Labor in the lower house. Carles went on to win the lower-house Fremantle seat through by-election in May 2009, ending 85 years of Labor Party representation. Standing against NPQ in favour of the people also 
featured in the campaign by which Brad Pettitt of The Greens won the Fremantle mayoral election in October 2009. Locals were antagonized by the imposing hypermodern NPQ settlement. Yet the project's master planner, Mike Day, seemed oblivious to its potential for antagonising locals through exclusion even though he envisaged NPQ reproducing colonial practice: 'We're trying to practise the kind of community building our forebears practised in the 1800s' (The West Australian, May 29, 2008). That kind of community building excluded and continues to exclude Aboriginal people from Fremantle (Cox 2011). The threat of a new round of colonization in the colony ${ }^{3}$ supported a variety of demands from subjects to protect aspects of Fremantle against encroachment by NPQ, and these demands constituted a unity that was most apparent during the 2009 Fremantle by-election campaign. Carles and audience members demonstrated this unity in the By-election Candidates Debate:

22:15 Adele Carles: ... Political donations from property developers. The big parties accept them. We don't, it's that simple.

22:41 Applause and cheers.

22:43 Adele Carles: If elected I'll be pressing for strict restrictions on... political donations. North Port Quay the developer has no more right to the seabed than you or I. This is public seabed... If this Dubai-style development goes ahead, it will be the kiss of death for our working port of Fremantle. (Kerr 2012a, 183)

Varied demands against NPQ were intertwined in the debate with positions against NPQ articulated by candidates in response to questions about policies and local concerns. The by-election debate and electoral campaigns also reproduced demands for local participation in policy making and for the people's participation in democratic governance. Although Poland and Day's monumental vision was excluded from the many advertisements for NPQ (Fremantle Gazette, April 18, 2009) during the byelection campaign, the project remained inscribed with meanings that evoked powerful 
negative responses in members of Fremantle community at a time when they were being reminded of public participation in policy making. Poland wrote to the press to limit damage to NPQ during the by-election and to destabilize the discursive frontier building against the project by attempting to constitute a unity with The Greens around ecological modernization:

Greens' advertising in recent weeks has called for investment in renewable energy. The Greens want to reduce WA's greenhouse gas emissions and promote sustainable communities... I want all of these things as well and with the support of world-renowned sustainability expert Peter Newman, I have committed my time and effort to achieving this... I would hope to work closely with the Greens and all Western Australians who share the common goal of sustainable development based on renewable energy. (Fremantle Herald, May 9, 2009)

Poland suggested that people had rejected NPQ because they thought it would destroy Port Beach (Fremantle Gazette, May 26, 2009). Corpus-supported analysis confirmed this reading of a populist discourse aggregating around the protection of beaches: the most common word appearing after the word 'our' in the corpus was 'beaches' as in 'our beaches' (Kerr 2012a). Eighteen incidences of 'our beaches' were found in the corpus (Table 1), followed by eight incidences of 'our city' then seven of 'our children' and seven of 'our state' (Table 2).

\section{<insert Table 1 here>}

Table 1. Incidents of 'our beaches' with narrow context in the corpus

$$
\text { <insert Table } 2 \text { here> }
$$

Table 2. List of at least 4 'our <word>' incidences found in the corpus

The word combination 'our beaches' first appeared in an expression about NPQ seeming like 'the end of Fremantle and our beaches' (Fremantle Herald, July 26, 2008). It was then articulated as 'Protect our beaches' by an image of The Greens candidates 
on Port Beach in a campaign advertisement (Fremantle Herald, August 16, 2008). This making a stand on 'our beaches' against housing over the seabed and other threats worked to signify a range of heterogeneous demands while constructing a frontier dividing society (Laclau 2005) into the people standing for 'our beaches' and those against them. For example, the following opinion column indicates a radical emotional investment in 'our beaches' that is not about the beach as such but about 'our' relation to the beach:

When I was a child I could walk all the way from South Beach... I could explore or fish almost anywhere... We have been physically cut off from much of our access to the beach and we are now being visually cut off from the water, for example by... North Port Quay... (Fremantle Herald, August 23, 2008)

Emotional investment in subjective attachment to beaches supported the mythical fullness of 'our beaches' functioning as the empty signifier linking a variety of demands (Laclau 2005) such as those mentioned further down the column:

... which brings up quite a number of unanswered problems. For example, the effects of climate change and rising sea levels, the erosion of beaches north of the development, the massive traffic problems that would arise when a population of 15,000 to 20,000 new residents are installed, and associated parking problems from this massive increase of traffic, the huge disruption throughout the whole development stage (up to 10 years), the blocking of the views of the ocean, etc. (Fremantle Herald, August 23, 2008)

The variety of demands - some clearly supported by the logic of existing relations of property ownership ${ }^{4}$ - incorporated by the empty signifier unified a discursive community frontier against those who would interfere with the subjective attachment of 'our beaches':

Confronted with NPQ and other developmental threats to the sea coast, most of us in the Perth region would strongly argue that our beaches are infinitely more 
important... than the narrowly-focussed, though massive-scale investment interests of the international and WA yachting/recreational boating lobby... Professor Peter Newman consistently fails to grasp this, despite his repeated usage... of the buzz word 'sustainability'... (Fremantle Herald, August 23, 2008)

Professor Newman attempted to breach this discursive frontier around the people of 'our beaches' against NPQ by positioning the project with the people in a letter to the Fremantle Herald:

Many people... have written saying we must protect our beaches from NPQ. NPQ will not harm beaches. It has been redesigned after public consultation... to be part of the protected beach system... (Fremantle Herald, August 30, 2008)

In the same edition, a full-page advertisement by Save Freo Beaches Alliance asked: 'Who can you trust to protect our beaches?' (Fremantle Herald, August 30, 2008). A facing page advertisement, for Adele Carles and another Greens candidate, answered: 'We will fight them on the beaches!' The NPQ threat became a major news event:

IT'S D-Day as developers continue their assault on our beaches, with the mother of all developments, the $\$ 10$ billion North Port Quay, announced for Rous Head. NPQ's six manmade islands will house 20,000 people... all surrounded by a 3.5 kilometre seawall to hold back rising sea levels. (Fremantle Herald, December 27, 2008)

NPQ's proponents responded before the Fremantle by-election with a new advertisement that attempted to bring 'our beaches' to its cause, at least figuratively (Fremantle Gazette, April 18, 2009). The advertisement was directed at disrupting the political frontier between it and the people by suggesting that NPQ was with the beach people. However, the frontier against NPQ was stabilized by images of true beach defenders in the by-election: Carles advertised that 'She is known for her passionate campaigns to save our beaches' (Fremantle Gazette, May 12, 2009); and Sam Wainwright campaigned: 'No North Port Quay - don't privatise our beaches' 
(Fremantle Herald, May 9, 2009). The NPQ consortium's attempt to appropriate the socially unifying power of 'our beaches' during the 2009 by-election campaign failed, but not for want of trying. A week before the by-election, a two-page advertisement for NPQ showed a famous former Australian cricketer on the beach playing cricket and saying:

\footnotetext{
Western Australians love going to the beach. It's a great place to have fun with the family and that's why I think our beaches need protecting for future generations to enjoy. (The West Australian, May 6, 2009)
}

However, this appropriation attempt to disrupt the discursive frontier forming between the people of 'our beaches' and coastal property developers failed due to the resilience of this frontier constituted out of readers' sensual encounters with beaches and prior knowledge of coastal development scandals. ${ }^{6}$ These tied in with sedimentary knowledge of beaches as symbolic borders for communities in Australia (Perera 2009).

Populist and institutional discourse around the NPQ issue coincided with the election of Carles to parliament. This electoral success relied on Carles being a known defender of 'our beaches' in the face of the threat of environmental destruction by NPQ. After Carles' victory, Fremantle Deputy Mayor John Dowson put a motion before council to reject NPQ. Dowson appealed for councillors to support this motion based on common sense that even 'a five-year-old' could see the project 'wouldn't work on environmental grounds' (Kerr 2012a, 245). However, councillor Strachan moved for deferral until a planning committee had reported on the project. A heated debate ensued with councillor Lauder supporting Dowson's rejection motion because 'the public has told us very clearly that the public don't want this' (Kerr 2012a, 245-246). However, inside the council chamber without an obvious discursive frontier, defending 'our beaches' faltered. Councillor Fittock argued that councillors were not in a position to 
represent the views of the people of Fremantle. Strachan argued that council could not decide the NPQ issue without a planning committee providing evidence to support that decision. On 23 September 2009, Fremantle council formally rejected NPQ based on the planning committee report's findings. Although this rejection was not expressed in terms of saving beaches, the motion was initiated and eventually passed in response to a popular demand within the equivalential chain of 'our beaches'.

The defence of 'our beaches' against NPQ can be understood as a localized popular movement to conserve beach aesthetics in which its subjects were motivated by contentment of their partial drives for 'simulacra of the lost (maternal) object' (Copjec 2004, 34). These drives to recover a forgotten sensual experience operate at a subconscious level, but were stimulated by imagery in the discursive contest around North Port Quay. Like the maternal object, the beach offers heterogeneity of meanings exceeding nature and culture categories in the symbolic mediation of discursive order. This excess meaning is the source of 'our beaches' symbolic power. Interestingly, suggestions of 'our beaches' were often combined with maternal symbols in the texts, such as the front-page photograph of Lynn MacLaren and Adele Carles taking a stand on the beach 'to put a protective green blanket over Freo's beaches' (Fremantle Herald, July 5, 2008). Campaign advertising positioned Carles as a competent local mother, appearing with daughters in hand by a slogan, 'CHANGE BEGINS HERE', and policy promises: 'protecting Fremantle tenancies, keeping our working port, and opposing offshore housing' (Fremantle Gazette, May 5, 2009). If these policies were changes, they were changes against emerging changes in Fremantle. Carles was positioned as a conservative against the impending threat of radical change to citizens' aesthetics from NPQ. This threat was agency for the powerful force of idealizing dissatisfaction with the unobtainable lost object, and Carles' campaigns effectively appropriated this 
powerful conservative reaction to the radical threat of NPQ. The desire of subjects to preserve place relations was described by Carles in her parliamentary maiden speech:

I am lucky to own a home in Fremantle, because Fremantle is a very special place, as anyone who is fortunate enough to live there will tell you. I live at the south end in an old renovated cottage amongst neighbours who are like family. We all know each other in this part of town. People walk and cycle; children roam in and out of our homes. People rarely sell their houses here. They are not interested in bigger houses, the latest appliances or new cars. There are no lock-down garages or security gates to keep people out. We have our doors open so that people can come in. It is almost old-fashioned, and I would not trade that for the world. It is this sense of connection and desire to preserve what is special that sees Fremantle people being active citizens and politically engaged. (Assembly 2009, 9)

Subject relations to place were threatened by the appearance of NPQ as a radical space for the continuation of capital accumulation. This finding supports the view of Harvey (2000) that a developer cannot create a utopian space ${ }^{5}$ without radically challenging existing social practices and their place relations because creating a utopian space is all about modifying social relations. Although project protagonists anticipated resistance, they did not expect the magnitude of local antagonistic reaction to their simulated spatial rendering of utopian social process that appeared in the form of North Port Quay. The ecological threats they represented in support of NPQ were read in heterogeneous ways that did not support a popular reading of the project as an environmental solution. Instead, spatially and temporally immediate threats from the project were more meaningful than the global future threats represented by project proponents. The spatial radicalism of this simulated, walled town off the coast of Fremantle triggered a powerful local conservative response operating through subjects' drives, represented as desire to conserve sensually experienced objects of the local coastal environment. This 
desire for 'our beaches' functioned as the equivalence required to link diverse people with diverse demands behind an effective discursive frontier.

\section{Conclusion}

The case of North Port Quay shows how the politics of green building is waged in discursive struggles over the space and time of environmental problems. Although proponents advertised that NPQ could 'lead the world in sustainable development' (Fremantle Gazette, February 10, 2009), people near the construction site did not see it that way because the project offered no solutions to the local, immediate environmental threats inscribed in it. Simulations of NPQ's great seawall reminded locals of the threat of rising sea levels which would be aggravated by emissions from the project's construction. Futuristic publicity renderings of NPQ supported representations of immediate beach damage from the project. Even arguments that NPQ would mitigate the future global threat of climate change were ineffective because this threat was considered by many locals to be an immediate threat to cherished local environment. The project was blocked by popular demand because spatially and temporally immediate threats were more meaningful and motivating than the distant future - postconstruction - threats suggested by North Port Quay's proponents. This motivational power was derived from a beach, a building, people and other things around the project site being sensed more intimately than mediated representations of global environment and its future problems. People in Fremantle responded conservatively when they saw their sensual relations to these things under threat. They were driven and unified by desire to continue to experience their cherished objects of local environment. The case of North Port Quay suggests that shared desire for continuation of past experience is what makes local responses to environmental threats so much more effective and immediate than regional, national or global responses. 


\section{Acknowledgements}

The author would like to thank Associate Professor Steve Mickler and Professor Niall Lucy for supervising this study, and Dr Vijay Devadas and Dr Aidan While for their feedback. This work was supported by the Commonwealth of Australia Government under an Australian Postgraduate Award and by Curtin University under a Curtin Research Scholarship and an Early Career Development Fellowship.

\section{Notes}

1. The event in $\mathrm{Oz}$ was located popularly in Fremantle, the colonial name for a port town in an area approximated with Walyalup in Nyoongar country. This public dispute over environmental meaning and spatial governance was waged within a colonial semiosis (Mignolo 2012) that enabled radical change in local land and water usage, such as the tearing open of the river mouth at Walyalup a century ago to support commercial and communication exchanges of British Empire to the detriment of Aboriginal trade and communications. The continuing process of colonisation of Nyoongar country is touched on only briefly in this paper. For more information, see note 3 below.

2. Hage $(2003,94)$ has described Australia's enduring problem of the 'unfished western colonial project... in a land of permanent decolonisation'. Hage (93) argues that there continues to be 'two communal subjects with two wills over one land; two sovereignties of unequal strength' in Australia. Although there were references to Aboriginality and native title claims in the case texts, NPQ was not located in Nyoongar country in public conversation of its environmental impact. Instead, the project was firmly located on 'public' land, particularly for the purpose of delegitimising NPQ by describing it as a privatisation project. It is worth noting that disputes over private versus public land have been a part of colonial occupation discourse in the area since the arrival of Captain Fremantle (Stratham-Drew 2003). While the private land category may support a more overtly 
aggressive form of colonization, the public land category has been employed effectively for marginalizing the spatial claims of Nyoongar people (Kerr and Cox 2013).

3. Even North Port Quay's offer of restoring marine life and sea-grass beds at the site was met by suggestions of its arrogance and subjective science in letters to the local press: "Who has determined that the bed in question is degraded and what is meant by degraded in this context?' (Fremantle Herald, 13 September, 2008).

4. The North Port Quay case is an example of the contradictory relations in urban development described by Harvey (2000), who argued that tensions in these relations were a product of a collision between spatial utopias and utopianism of the free-market process. Ideal places were threatened by the coming to ground of free-market utopianism, requiring new spaces for capital accumulation to continue.

5. It is not difficult to identify similarities between the reclaimed island project of North Port Quay and Thomas More's (1999) artificial island of Utopia.

6. The Corruption and Crime Commission (2008) investigated allegations of municipal-council manipulation by developers of large coastal properties. Public hearings were held by the commission in relation to Smiths Beach in 2006 and to Port Coogee (just south of Fremantle) in 2007. The Port Coogee hearings publicized the large cash donations made by proponents of the Port Coogee project to the then Cockburn Mayor, Stephen Lee, to fund his successful re-election campaign. Through these public hearings and their media coverage, the community of Fremantle and Western Australia learnt about the alleged wrongdoings of coastal property developers and how their consultants and lobbyists affected the outcomes of municipal elections and the partiality of public officials.

\section{References}


$A B C$ News WA, 2008. "WA Premier Criticises Fremantle Island Plan.” TV, ABC1 Perth. May 29.

Assembly, 2009. Hansard 4685d-4742a, 7-11.

Bakker, K., and Bridge, G. 2006. "Material Worlds? Resources Geographies and the 'Matter of Nature'." Progress in Human Geography 30 (1): 5-27. doi: 10.1191/0309132506ph588oa.

Bhatia, V. K. 2008. "Towards Critical Genre Analysis." In Advances in Discourse Studies, edited by V. K. Bhatia, J. Flowerdew and R. H. Jones, 166-177. London: Routledge.

Chouliaraki, L. 2008a. "Discourse Analysis." In The SAGE Handbook of Cultural Analysis, edited by T. Bennett and J. Frow, 674-696. London: SAGE.

Copjec, J. 2004. Imagine there's no Woman: Ethics and Sublimation. Cambridge, MA: MIT Press.

Corruption and Crime Commission. 2008. Report on the Investigation of Alleged Misconduct Concerning Mr Stephen Lee, Mayor of the City of Cockburn. Perth.

Cox, S. 2011. "Voicing the Unseen in Fremantle's Kings Square: Re-instating Fremantle's 'Civic-heart' and the Exclusion of Aboriginal Groups.' In The Eleventh Humanities Graduate Research Conference: Voicing the Unseen, edited by S. Adams, C. Gomersall, J. Lunn, C. Pflaumbaum, J. Ryan and A. Yeow.

Dahlgren, P. 2009. Media and Political Engagement: Citizens, Communication, and Democracy. New York: Cambridge University Press.

Dryzek, J. S. 2005. The Politics of the Earth: Environmental Discourses. Oxford: Oxford University Press.

Freud, S. 1991. Introductory Lectures on Psychoanalysis. Translated and edited by J. Strachey. London: Penguin Books.

Gottweis, H. 2008. "Participation and the New Governance of Life." BioSocieties 3: 265-286. doi:10.1017/S1745855208006194.

Gregg, M., and Seigworth, G. J. 2010. The Affect Theory Reader. Durham: Duke University Press.

Hage, G. 2003. Against Paranoid Nationalism: Searching for Hope in a Shrinking Society. Annandale: Pluto Press Australia.

Hajer, M. A. 1995. The Politics of Environmental Discourse: Ecological Modernization and the Policy Process. Oxford: Oxford University Press.

Hajer, M. A. 2003. "A Frame in the Fields: Policymaking and the Reinvention of Politics." In Deliberative Policy Analysis: Understanding Governance in the Network Society edited by M. A. Hajer and H. Wagenaar, 88-110. Cambridge: Cambridge University Press.

Harvey, D. 1996. Justice, Nature, and the Geography of Difference. Cambridge, MA: Blackwell Publishers.

Harvey, D. 2000. Spaces of Hope. Edinburgh: Edinburgh University Press.

Howard, E. 1946. Garden Cities of To-morrow. London: Faber and Faber.

Howarth, D. 2000. Discourse. Buckinghamshire: Open University Press.

Kenworthy, J. R. 2006. "The eco-city: ten key transport and planning dimensions for sustainable city development." Environment and Urbanization 18 (1), 67-85. doi:10.1177/0956247806063947.

Kerr, T. 2009. "Sustainability Discourse, Place and the Green Building." In The Ninth Humanities Graduate Research Conference: engaging place(s)/engaging culture(s) edited by J. Baldwin, J. Baker, H. Fordham, J. Grellier, C. Houen, T. Kerr and A Reid. 
Kerr, T. 2012a. "Representing Ecological Threats and Negotiating Green Built Environment." PhD Diss., Curtin University.

Kerr, T. 2012b. "Reproducing Temples in Fremantle." International Journal of Heritage Studies, 18 (1), 1-17.

Kerr, T., and Cox, S. 2013. Setting up the Nyoongar Tent Embassy: A Report on Perth Media. Perth: Ctrl-Z Press.

Koeppel, S., and Ürge-Vorsatz, D. 2007. Assessment of policy instruments for reducing greenhouse gas emissions from buildings. Budapest, United Nations

Environment Programme and Central European University. Accessed April 18, 2012. http://www.unep.org/sbci/pdfs/SBCI_CEU_Policy_Tool_Report.pdf

Kristeva, J., and Goldhammer, A. 1985. Stabat Mater. Poetics Today 6 (1/2), 133-152. doi: $10.2307 / 1772126$

Lacan, J. 1981. The Four Fundamental Concepts of Psychoanalysis: The Seminar of Jacques Lacan XI .Translated and edited by A. Sheridan. New York: W. W. Norton.

Laclau, E. 2005. On Populist Reason. London: Verso.

Laclau, E. 2006. "Why Constructing a People is the Main Task of Radical Politics." Critical Inquiry 32 (4), 646-680. doi:10.1086/508086.

Latour, B. 2004. Politics of Nature: How to Bring the Sciences into Democracy. Translated and edited by C. Porter. Cambridge, MA: Harvard University Press.

Lee, D. Y. W. 2008. "Corpora and Discourse Analysis: New Ways of Doing Old Things." In Advances in Discourse Studies, edited by V. K. Bhatia, J. Flowerdew and R. H. Jones, 86-99. London: Routledge.

Lucy, N., and Mickler, S. 2006. The War on Democracy: Conservative Opinion in the Australian Press. Crawley, WA: University of Western Australia Press.

Massola, J., Arup, T., and Aston, H. 2014. The Four who Brought Together Clive Palmer and Al Gore. Accessed September 30, 2014. http://www.smh.com.au/federal-politics/political-news/the-four-who-broughttogether-clive-palmer-and-al-gore-20140626-3awgy.html

Mignolo, W. D. 2012. Local Histories/Global Designs: Coloniality, Subaltern Knowledges, and Border Thinking. Princeton: Princeton University Press.

Miller, J. 2010. "Tackling Global Climate Change: Meeting Local Priorities." World Green Building Council. Accessed August 3, 2011. http://www.worldgbc.org/images/stories/worldgbc_report2010.pdf

More, T. 1999. "Utopia" In Three Early Modern Utopias: Thomas More: Utopia / Francis Bacon: New Atlantis / Henry Neville: The Isle of Pines, edited by S. Bruce, 1-148. Oxford: Oxford University Press.

O’Neill, K. J., and Gibbs, D. C. 2013. "Towards a Sustainable Economy? Sociotechnical Transitions in the Green Building Sector." Local Environment: The International Journal of Justice and Sustainability, doi:10.1080/13549839.2013.818954.

Osborn, F. J. 1946. "Preface.” In Garden Cities of To-morrow, edited by F. J. Osborn. London: Faber and Faber.

Perera, S. 2009. Australia and the Insular Imagination: Beaches, Borders, Boats, and Bodies. New York: Palgrave Macmillan.

Rapley, T., and Flick, U. 2007. Doing Conversation, Discourse and Document Analysis. London: Sage Publications.

Scollon, R., and Scollon, S.W. 2003. Discourses in Place: Language in the Material World. London: Routledge. 
Shapiro, M. 2001. "Textualizing Global Politics.” In Discourse Theory and Practice: A Reader, edited by M. Wetherell, S. Taylor and S. Yates. London: Sage Publications.

Stratham-Drew, P. 2003. James Stirling: Admiral and Founding Governor of Western Australia. Crawley, WA: University of Western Australia Press.

Thrift, N. 2008. Non-representational Theory: Space, Politics, Affect. Milton Park, Abingdon: Routledge.

While, A., Jonas, A.E.G., and Gibbs, D. 2004. "The Environment and the Entrepreneurial City: Searching for the Urban 'Sustainability Fix' in Manchester and Leeds." International Journal of Urban and Regional Research 28 (3): 54969. doi:10.1111/j.0309-1317.2004.00535.x.

While, A., Jonas, A.E.G., and Gibbs, D. 2010. "From Sustainable Development to Carbon Control: Eco-state Restructuring and the Politics of Urban and Regional Development." Transactions of the Institute of British Geographers 35 (1), 7693. doi:10.1111/j.1475-5661.2009.00362.x.

World Commission on Environment and Development. 1987. Our Common Future. Oxford: Oxford University Press. 